\title{
Albert Einstein Library: From Princeton to Jerusalem
}

\author{
Marianna Gelfand \\ The Library Authority, The Hebrew University of Jerusalem, Jerusalem, Israel
}

Email address:

mariannag@savion.huji.ac.il

\section{To cite this article:}

Marianna Gelfand. Albert Einstein Library: From Princeton to Jerusalem. American Journal of Information Science and Technology. Vol. 3, No. 4, 2019, pp. 80-90. doi: 10.11648/j.ajist.20190304.11

Received: August 18, 2019; Accepted: September 12, 2019; Published: October 15, 2019

\begin{abstract}
This article, based on both historical and content analysis of Albert Einstein's private library, presents a comprehensive picture of the Einstein Collection that was located at his home in Princeton, now housed at The Albert Einstein Archives at The Hebrew University of Jerusalem. His private library consisted of approximately 2,400 titles, including not only books but also a small collection of journals, musical scores and records. Staff members of the Archive succeeded in adding additional books, including works by Einstein himself and ones about him in various languages. These amounted to approximately 1,500 titles. Most of the books in Einstein's library related to subjects other than physics. Many authors presented copies of their books to Einstein. Those books, usually with autographs or dedications by the authors, dealt with various fields of knowledge - philosophy, literature, religions, Jewish culture, etc. Content analysis of Einstein's personal library reveals scientific, political, and social connections of the scientist. This article includes information about the main institutions involved in conveying the library to Jerusalem and in organizing it. These were the American Friends of The Hebrew University in New York, the Japan Broadcasting Corporation, and the Jewish National and University Library (today The National Library of Israel). The primary sources for the research on which this article is based are 1) material from The Albert Einstein Archives at The Hebrew University of Jerusalem, 2) Inventory Books of the National Library of Israel, 3) Kiryat Sefer, bibliographical quarterly of the Jewish National and University Library, 4) Einstein's reprint collection at The Weizmann Institute of Science. The following conclusions were drawn: 1) From the Einstein private library items were given as gifts both during his lifetime and after his death; 2) a large proportion of the books that Einstein gave to the National Library of Israel were registered in the Inventory Books of the National Library of Israel before the transfer of his complete library to Jerusalem; 3) Einstein's personal library includes books that actually belonged to other members of his family. For example, there are books, like those that belonged to his secretary Helen Dukas and to his stepdaughter Margot Einstein, that contain either the signature of the former owner or autograph/dedication by the author of the book. The article's references to the contemporary Israeli press about Einstein's visit to Israel elucidate Einstein's role in the founding of The Hebrew University of Jerusalem.
\end{abstract}

Keywords: Albert Einstein, The Albert Einstein Archives, The Hebrew University of Jerusalem, Einstein's Personal Library, Dedications

\section{Introduction}

In 2012, I was entrusted with classifying and cataloging Albert Einstein's private library at The Einstein Archives at The Hebrew University of Jerusalem. During my work I became highly motivated to research and to understand the fate of Einstein's library. The following questions arose, among others: How did the library come to Israel from Princeton? Who did contribute to make the transfer of the library possible? Do the Archives contain all his books? To which extent does the library reflect Albert Einstein's scientific, social, and political interests and relationships?

I present the results of my research according to the relevance of its different aspects, rather than in a chronological order.

The research is based on the Archives' materials, local Hebrew press, The National Library's inventory books, the bibliographical quarterly of the Jewish National and University Library (Kiryat Sefer), the Einstein reprint collection at The Weizmann Institute of Science, and several biographies on Einstein. 


\section{The Einstein Library}

After the death of Albert Einstein, his library was transferred from his home at 112 Mercer Street in Princeton, New Jersey in the United States to the Jewish National and University Library (hereafter JNUL) in Jerusalem in 1987.

In reaction to this event, Professor Gerald Holton (Harvard University) wrote in a letter to the collection's new home, "Unlike the fate of Newton's library, Einstein's was at least lucky in getting a "home" only a few decades after his death." [1]

Einstein's personal library consisted of approximately 2,400 titles, mainly books, including multi-volume collections, a small quantity of journals, and several hundred musical scores and 200 records.

The library originally also included books belonging to members of Einstein's family. Although Einstein, of course, had access to these books, most of them were eliminated from the collection when it was processed and catalogued after its arrival in Jerusalem. The time and efforts of the JNUL were mainly directed toward the materials belonged to Einstein himself. In addition, JNUL staff members were not aware that the Einstein's library would eventually belong to The Hebrew University and the planning of his archive there did not take into account all the books of his library. [2]

Cataloguing of the Einstein materials was carried out with financial support from the Japan Broadcasting Corporation (Nippon Hoso Kyokai, or Japanese State Television, hereafter NHK). The Agreement between the Jewish National and University Library (located at The Hebrew University of Jerusalem) and the NHK was signed on December 16, 1987 and "amended and ratified on April 25, 1988." [3] The project, including the cataloguing of books in Hebrew and Yiddish and the musical scores, was completed by November 1990. [4] The Japanese television series prepared at the same time by Japanese television made use of items from the Einstein archive of the JNUL and the Einstein library for its six-part documentary "Einstein - His Message to the Citizens of the World in the $21^{\text {st }}$ Century." [5]

In addition, a memorandum (referred to as Agreement II) was signed between the NHK and the JNUL on November 22, 1989 stipulated that "The publication of the English edition of the catalogue is scheduled for 1991." [6] However, as far as is known, this project for an academic publication of a catalogue of the Einstein library did not take place.

Within the framework of Agreement II, Prof. Tsutomu Kaneko (University of Osaka Prefecture) noted what he referred to "the overall characteristics of the bibliotheca [i.e., library]." [6] In his unpublished essay 'Einstein at Reading Some Topics in his Personal Library' [1990] Professor Kaneko pointed out two, in his opinion, unique features of the collection: "...the rare collection of the geometry and science books which Einstein seemed to study [to have studied] in his youth and the extraordinary collections of dedications, autographs and inscriptions in the books." [7]

Almost one fifth of the books in the collection contain dedications to Einstein. These were usually written by the authors of the books, but sometimes also by the translators, editors, or illustrators. Other books had been presented to Einstein by acquaintances, friends, his physician, members of his family, or by other people.

During the preparation of the catalogue of the library, a decision was taken in March 1989 to indicate the presence of every dedication in a book, the name of the person who presented the book, the person to whom the book was dedicated, and the date of the dedication. [8]

An effort was made during the cataloguing to provide additional information about the dedications and the autographs (names or initials of author, donor, or owner of the item) in the books, as well as annotations, corrections, calculations and other signs. Unfortunately, not all such information in the catalogue is complete or precise. Even at the present time one finds in the catalogue details that need to be corrected or supplemented.

Of particular interest are notes written in Einstein's own hand. According to Kaneko, such exist. He claimed that "The number of volumes in which we have found some notes by Einstein is more than thirty." [9] He included in his total "any manuscript [i.e., handwritten] addition to the volumes, varied [that ranged] from at least one word or sign to a whole page or more." [9]

A more accurate count was made by Ze'ev Rosenkranz (who was an archivist/curator of the Albert Einstein Archives from 1989 to 2003 [10]): "To our mind, there are far fewer instances of marginalia by Einstein himself (in c. 20 books) than Prof. Kaneko believes." [11]

Ze'ev Rosenkranz copied "the texts of dedications in AE's books." In a letter he noted that he himself copied the dedications in German and English, while his assistant did so for those in English and French. [12] The files with these copied out dedications can be found today in the Einstein Archives.

In additional to scientific books the Einstein library contains book of philosophy, classical literature (mainly in German and English), and books about history, sociology, Judaism and other religions, music, etc. The library contains about one hundred books, of which Einstein himself was the author, co-author, and author of the introduction (to 20 books).

Ze'ev Rosenkranz noted the perhaps surprising fact that “...Einstein's library does not include prolific number of works strictly related to physics." [13] When compiling

information about Einstein's books, Rosenkranz attempted to find out whether, in addition to books from the scientist's home, books were sent to Jerusalem from Einstein's office at the Institute for Advanced Study in Princeton. Rosenkranz even included in one of his letters two photographs presumably of Einstein's office, which were published in two books about the scientist: A. P. French (ed.). Einstein: A Centenary Volume (Cambridge, Mass., 1979) and Ronald W. Clark. Einstein - The Life and Times (New York, 1971). [14]

However, in response Ehud Benamy (assistant administrator of the Einstein Archives at The American Friends of The Hebrew University, Inc., New York), who was 
responsible for the packing and sending of Einstein's books, corrected the error. The photographs were not of Einstein's office but of a classroom in which Einstein had worked. However, he did note that "The classroom pictures do, indeed, show some books on the shelves." [15]

While Benamy was not certain about the fate of the books from Einstein's office, he assumed that they were transferred to Einstein's home on Mercer St. in 1955. [16] In any case, Benamy shared the view of Rosenkranz about the collection in Einstein's home. Benamy stated: "Regarding the sparcity [i.e., sparsity] of books on physics in Einstein's personal library at Mercer Street, I too took notice that most of the books were unrelated to physics. Many authors sent him autographed volumes, everything from philosophy, literature, history, and sundry subjects." He continued: "I often wondered whether Einstein ever got around to reading his extensive collection. I have my doubts." [15]

Prof. Gerald Holton collected materials that he expected would help him write a description of Einstein's library. [17] However, evidently, this effort was not crowned with success.

The idea was that Professor Holton would write the preface to the International Academic Publication of the Catalogue of the Einstein Library, while Ze'ev Rosenkranz would write a historical essay about the library and its composition and Professor Kaneko would present a summary of the "overall characteristics of the bibliotheca." [6]

In his essay that was commissioned by the NHK, Rosenkranz focused on two major events that affected the fate of the Einstein library, the scientist's move from Berlin to Switzerland in 1914 and the transfer of the books from Berlin to Princeton in 1933, noting that manuscripts of Einstein were saved via the French Embassy in Berlin. [18]

Rosenkranz discovered "a list of publications on relativity in his [the scientist's] Berlin library which was sent by Einstein [in fact, by his secretary] to the Deutsche Gesellschaft fuer Auslands-Buchhandel [in] Leipzig." [19] Rosenkranz also found a document in which Einstein expressed his appreciation to the cataloguer of his Berlin library. Einstein wrote as follows on December 15, 1938: "I herewith certify that Mrs. Hanne Fanta has rendered me the great service some years ago to catalog my library." [20] Thus, we know that, before its transfer across the Atlantic, Einstein's Berlin library was organized and catalogued by Johanna (Hanne) Fantova, the wife of Professor Otto Fanta. [21]

Ilse (Einstein's stepdaughter and first secretary), together with her husband Rudolf Kayser [22] (who wrote a biography of Einstein under the pseudonym Anton Reiser) and her sister Margot (also the Professor's stepdaughter, who later lived in Einstein's house in Princeton) arranged the salvaging of Einstein's personal papers from his Berlin apartment. Before the Nazis were able to get their hands on some of Einstein's papers in Caputh, Kayser rescued this material. As An Einstein Encyclopedia stated: "These papers and files constituted the earliest form of what later became the Einstein Archives." [23]
The author of this article has not been able to ascertain details about this rescue from Einstein's summer home in Caputh, but Peter A. Bucky, a son of one of Einstein's friends, provided some historically important information. He wrote that: "The Nazis continued and confiscated Einstein's bank account and looted his summer house in Caputh, and they seized his writings, books and papers in order to deliver them later to the flames at the book burning, which took place at the Opernplatz in Berlin, the $10^{\text {th }}$ of May 1933, together with other "Schriften undeutschen Geistes" [in Nazi terminology: writings alien to the German spirit]." [24] According to Helen Dukas everything of importance in Einstein's Berlin apartment was saved and transferred to America. [25]

Einstein's library found a permanent home in 1987, when its arrived by sea in Israel.

According to Einstein's will, that was drawn up on March 18, 1950, all his books were bequeathed to Helen Dukas (his secretary from 1928 to 1955), who had become, as noted by Einstein's biographer A. Pais, a trusted secretary, as well as a member of his family. [26]

The following are excerpts from the will: [27]

"THIRD:

I give and bequeath my books and all of my personal clothing

and personal effects, except my violin, to my secretary, HELENA DUKAS.” [28]

FOURTH:

I give and bequeath my violin to my grandson, BERNHARD CAESAR EINSTEIN." [28]

Dr. Otto Natan and Helen Dukas were named "as trustees of trust..." [29] The will stipulated that the ultimate owner of his literary rights and property would be The Hebrew University in Jerusalem:

"Upon the death of the said HELEHA DUKAS and the said MARGOT EINSTEIN, this trust shall terminate ... and all literary rights and property, shall pass and be distributed to HEBREW UNIVERSITY..." [30]

After the death of Elsa, Einstein's second wife, "Dukas became housekeeper in the Mercer Street home in addition to carrying out her duties as secretary." [31] Together with the mathematician Banesh Hoffmann, Dukas was the co-author of Albert Einstein, Creator and Rebel, 1972 and co-edditor of Albert Einstein, the Human Side, 1979. [32]

\subsection{Sending Einstein's Home Library to Israel}

The person responsible for sending Einstein's home library was the above-mentioned Ehud Benamy, who was then working in New York of the American Friends of The Hebrew University [hereafter Friends]. The letter of gratitude sent by Margot Cohn (a staff member of the Department of Manuscripts and Archives of the JNUL) sent to Benamy on January 26, 1987 reports the reception of a package sent by him containing photo-copies of the title pages of the books that he had prepared to be sent. These items included books from Einstein's personal library, as well as book that had belonged to Margot Einstein and Helen Dukas. [33] 
On January 15, 1987 Ehud Benamy wrote to Margot Cohn in Jerusalem: "The books are being shipped on Zim "Iberia", voyage 17 East, departed January 12 and expected arrival on January 26." [34]

On August 25 Benamy reported to the same addressee:

"[I] Am today sending via the Israel Consulate five cartons containing medals, awards, albums, books, photographs, etc.

This is final shipment of Einstein material from his Princeton home." [35]

Thus, the packing and dispatch of these items, that had taken seven and a half months, was completed in August 1987.

On the basis of the title pages (mentioned above), which are today kept in the Einstein Archives, we are able to understand the organization of the library in Einstein's home.

Also on this basis we can learn about books that were not included in the Einstein Collection, ones from the personal libraries of Margot Einstein and Helen Dukas. The latter two groups constituted more than 320 titles, of which a considerable number were books on art, works of literature (several books by Rilke and Tolstoy), works about Israel, Jewish culture, books about cities of the world, and books about animals. The topics of some of them indicate that they belonged to Margot, who was a professional sculptor. The reason for the exclusion of these books from the collection of the Archives is indicated by a note that was placed in the box with the photo copies of the title pages. The relevant words were: "Out of score books from Helen Dukas \& Margot Einstein for distribution. Post-1955 + not inscribed or autographed". In other words, the books were not included in the Einstein Collection since they were mainly published after Einstein's death in 1955 or did not contain either a dedication or a signature. However, due to the mistake of a librarian, one such book was not excluded. This was Ronald Searle's Looking at London and People Worth Meeting (London: News Chronicle, 1953). Perhaps the inclusion of this item resulted from the autograph of Helen Dukas, that was discovered after the previous decision to exclude it.

A search by the author of this article in the collections of the National Library of Israel revealed that some of the books that had belonged to Margot Einstein and Helen Dukas were to be found there. Others, however, were perhaps distributed to other libraries. This assumption about such a distribution reflects not only the note discussed above, but also information recorded in Kirjath Sepher (or Kiryat Sefer), the bibliographical quarterly of the Jewish National and University Library, regarding the policy of this library. That source (from decades before the arrival of books from Einstein's home) notes that the Library's policy was to facilitate the transfer of duplicate works to other libraries in Israel and to ones abroad. [36] Kirjath Sepher also mentions books being selected for exchange. [37]

At the same time the librarians made great efforts to keep books that had belonged to the members of Einstein's family and to his secretary in which there was a dedicatory inscription or an autograph. Approximately 50 books with dedicatory inscriptions to Margot, Helen, Elsa, or Ilse were kept in the collection of Einstein's home library at the Archives. Also preserved there were about two dozen books with the autograph of the books' owners, including both of Einstein's sons-in-law-Rudi [Rudolf] Kayser \& Dim. [Dimitri] Marianoff. Like Kayser, Dimitri wrote a book about his father-in-law (Marianoff's book was Einstein: An Intimate Study of a Great Man). These totals do not include inscriptions in items in the musical collection of the Einstein's library.

Since many of the books in the Einstein Collection were in need of repair, the Archives began a restoration project in July 2012 .

\subsection{Einstein's Gifts}

Notes of JNUL employees and their correspondence with the Friends indicate that work was carried out to trace the fate of those books from Einstein's personal library which were not included among his books that were sent to the JNUL.

It is likely that the books from Einstein's office at the Institute for Advanced Study in Princeton were packed after his death by his secretary and were located in the scientist's home before the dispatch to Jerusalem. [11]

Einstein had occasionally sent books and journals to the Jewish National \& University Library. Ze'ev Rosenkranz found (apparently in the JNUL archive) the first evidence dating to 1927, when the scientist was still in Berlin, of the receipt of materials from Einstein, and of more numerous items received in 1953 and 1956. [11] This evidence discovered by Rosenkranz facilitated my search for information about the JNUL's registration of acquisitions from Einstein's library.

My first source regarding the JNUL acquisitions was the already mentioned Kirjath Sepher. Examination of issues from no. 1 (1924-1925) through no. 33 (1958) [38] significantly supplemented the information that had been provided by Ze'ev Rosenkranz.

The 1932 issue (Vol.8, No.3) reported the receipt of two boxes of scientific journals and books from Einstein. The issue said: "Professor Einstein once again sent two boxes with journals and books on physics, mathematics, and related fields. Some of the books deal with research in the field of the theory of relativity and to a significant degree supplement the collection of books on that topic in the Beit ha-Sefarim [the previous name of the JNUL]." [39] In the text of the report the Hebrew expression "hazar ve-shalakh" (here meaning "once again") confirms the receipt of previous gifts from Einstein.

Vol. 17, No. 1 (1940) of Kirjath Sepher reports Einstein's gift of several recent books. [40]

Kirjat Sepher contains no information about the relatively large gifts that Einstein sent to the JNUL in the 1950s since during that period the library bulletin no longer included the section "News of the library", which in addition to news of various activities of the library included information about donations, gifts, and purchases. [41] However, it was possible to retrieve such information on the basis of the 
inventory books which have been preserved at the JNUL. These registers including the names of books acquired between 1936 and 1990. Each entry includes the title of the publication and, usually, the place and year of publication, the name of the donor (if there was one) and the topic of the publication and the language in which it was written. The acquisitions were divided into four categories, with the entries of each of them being listed in separate volumes. The volumes labeled "D" contained entries about scientific books written in European languages. The volumes labeled " $\mathrm{C}$ " contain entries about book in the humanities that were written in European languages. The volumes labeled "B" contains entries about books on Jewish history, culture, and religion written in European languages, while the volumes labeled "A" contain entries about books on Jewish history, culture, and religion written in languages that used a Hebrew alphabet, e.g., Hebrew, Yiddish, and Ladino.

In the "donor" section of the inventory books the name of Einstein appears sometimes in English and sometimes in Hebrew, sometimes with the title or "Professor" or "Dr." and sometimes without.

The inventory books relating to the post-1955 period sometimes the section "donor" has the bi-lingual entry 'Einstein עזבון' [in English: 'Einstein legacy'] that indicates the registration of a book after the death of the donor (for example, in $57 \mathrm{D}$, in bound volume 55-59 D, date: 29.9.57).

Several dozen books of Einstein are registered in this historical document of the National Library, books on physics, chemistry, mathematics, the history of science and medicine, as well as on history, sociology, psychology, religion, etc. These books were mainly published between the 1930s and 1950s, mostly in English, German, and French. The presence of a relatively large number of scientific books among these entries confirms the first, 1932, report in Kirjath Sepher about the receipt from Einstein of books "on physics, mathematics, and related subjects." According to information from staff members of the National Library, the gift books that were received in a given year were sometimes included in the inventory books over a period of years. It is possible that this fact explains the registration of Einstein's books in the inventory books for 1938-1940 that Kirjat Sepher records as having arrived in 1932 .

This would be the case, of course, if there were no additional acquisitions between 1932 and 1940.

Entries were recorded in the inventory books starting in 1936. For this reason, it was not possible to determine from this source the receipt of Einstein materials for 1927. Ze'ev Rosenkranz mentioned another source when he was discussing the arrival of Einstein books from Berlin. Sources noted above, that were checked, referred to the gifts that Einstein sent from Princeton. Sometimes bibliographical information (indication of the place from which material was sent) is included in the "donor" section as follows: Princeton Prof. A. Einstein [42] (in 40 B, in bound volume 40-41 B).

The relatively large number of entries about books donated by Einstein in the 1950 s (especially in $53 \mathrm{D}$, in bound volume 48-54 D) corresponds to the information provided by
Ze'ev Rosenkranz about acquisitions in 1953 and 1956. The letter of appreciation to Einstein written by Curt Wormann (who was the director of the National Library) supplements the other information about the 1953 acquisitions: "We were much gratified to receive about 215 most valuable books you received from authors and publishers." [43]

In the process of the research reported here, in the inventory books, the author of the present article examined entries about books published in European languages from 1936 to 1957 or 1959 (volumes D, C, and B). However, entries for items that were listed in category "A", i.e., in languages in Hebrew script, were not examined. The reason for this is that Einstein did not know Hebrew even though he began his historical speech on Mount Scopus in Jerusalem with greetings in Hebrew.

Einstein noted in his travel diary: "I had to begin with a greeting in Hebrew, which I read with great difficulty." [44]

He continued his scientific lecture in French, commenting that if the public did not fully understand his scientific lecture on the theory of relativity, it would not only be because of his lack of mastery of the language... [45]

\subsection{Dedications and Autographs}

In 1948 Einstein sent via Prof. Chaim L. Pekeris, who moved from Princeton to Israel, to The Weizmann Institute "a collection of reprints of articles sent to him over the years by colleagues." [46] Along with correspondence with the authors of articles, at that time such reprints were a common means of contact between scientists. [47]

The Einstein reprint collection at The Weizmann Institute [48] is contained in 59 bound volumes, the last of which is the index to the previous ones. The materials are presented in alphabetical order according to the name of the author. The publications mainly deal with physics and dated from the late 1880 s to the 1940 s. Many of the articles had originally been published in three journals: Annalen der Physik, Physikalische Zeitschrift, and Zeitschrift für Physik, which appeared in the 1910s and the 1920s. The collection of reprints is impressive both for the quantity of reprints that had been sent to Einstein and for the number of their dedications and autographs.

Inter alia, they include the following items:

1) the typed dedication by Austrian physicist Ernst Mach that accompanied his article: 'Über den Einfluss räumlich und zeitlich variierender Lichtreize auf die Gesichtswahrnehmung', Sitzungsberichte der Kaiserlichen Akademie der Wissenschaften in Wien, 115, 633 (1906):

"Herrn Prof Dr A Einstein

hochachtungsvoll d V."

("To Prof. Dr A Einstein

respectfully the A [uthor]") [49]

2) the handwritten dedication by the Danish physicist Niels Bohr that accompanied a reprint of his article: 'Natural Philosophy and Human Cultures', Congrès International des Sciences Antropologiques et Ethnologiques (1938):

"Prof. A Einstein

with kindest regards 
of the author." [50]

3) an emotional handwritten dedication, written in German, accompanying the article of Einstein's close friend the physicist Paul Ehrenfest: 'A Mechanical Theorem of Boltzmann and Its Relation to the Theory of Energy Quanta', Proceedings Koninklijke Akademie van Wetenschappen te Amsterdam, 16, 591 (1913):

"Dem lieben, lieben Einstein

zur Erinnerung an

1914 - Leiden"

("To dear, dear Einstein

in remembrance of

1914 [in] Leiden") [51]

4) the handwritten dedication by Ehrenfest's wife, the mathematician T. [Tatyana] Ehrenfest-Afanassjewa that accompanied her article 'Der Zahlbegriff und die Erfahrung', Euclides, Tijdschrift voor de Didactiek der Exacte Vakken (1936):

"Dem leiben Herrn Einstein

von der Verfasserin."

("To dear Mr. Einstein

from the author") [51]

5) the autograph, together with a handwritten dedication by the Israeli physicist Adolf Fraenkel: 'Über die Teiler der Null und die Zerlegung von Ringen', Journal für die reine und angewandte Mathematik, 145, 139 (1920):

"Herrn Prof. Einstein

in ehrfurchtsvoller Hochacht.

22.1.20"

("To Prof. Einstein

with reverent respect.

22.1.20"). [52]

Vol. 17 of the Einstein reprint collection also contains Adolph Frankel's article 'Die Axiome der Mengenlehre', that was published in the first scientific collection of the Hebrew University: Scripta Universitatis atque Bibliothecae Hierosolymitanarum, 1 (1923), of which Einstein himself was the editor.

The reprint collection (vol. 11) also includes a copy of the thèses [doctoral thesis] of Irène Curie 'Recherches sur les rayons $\alpha$ du polonium...' (Paris, 1925) who, like her parents Pierre and Marie Curie, was awarded the Nobel Prize. [53] The following handwritten dedication on is on the cover:

"Ă Mr. Einstein

Hommage respectueux

I. Curie"

("To Mr. Einstein

With great respect

I Curie"). [54]

It may be noted that this reprint was never cut open, indicating that, apparently, it was not opened by Einstein.

Some books from Einstein's personal library were given as gifts to certain individuals. In a private conversation, that was cited by Gerald Holton, Helen Dukas noted that "after Einstein's death she, as co-inheritor of his books, gave some of them away to certain people (she did not identify them) who had been close to Einstein and had been 'kind to the family' in the trying days of his last illness." [55]

Among these recipients of Einstein's books was Nathan Rosen, Einstein's "first American assistant." [56] Prof. Rosen received as a gift The History of Mechanics (1897) by Ernst Mach. [57] The reading of that book had made a strong impression on the young Einstein. [58] In addition to that work Rosen received from Helen Dukas: Hermann von Helmholtz's, Die Lehre von den Tonempfindungen [als physiologishe Grundlage für die Theorie der Musik] (1896) and Max Planck's, Vorlesungen über die Theorie der Wärmestrahlung (1906). [59]

In 1973 Ms. Dukas sent to the Swiss physicist Prof. Res Jost the booklet 'Die Grundlagen der Einsteinschen Gravitationstheorie' (1917) by Erwin Freundlich. The recipient of the latter gift noted Dukas' grounds for bestowing such items: "Helen made presents of some of these books to people whom she liked. I was such privileged." [60]

"Einstein's reprints in the 4-volume set of [his] reprints" were presented to Prof. Holton. [61] Evidently, that gift was bestowed in the context of the joint work conducted by Dukas and Holton: "In the 1960s, Helen Dukas and Gerald Holton of Harvard University started to systematize the material, thereby rendering it accessible to scholars and preparing it for eventual publication in The Collected Papers of Albert Einstein, a joint project of The Hebrew University and Princeton University Press." [62]

But aside from her gifts to individuals, in her correspondence Helen Dukas noted that from time to time, when the shelves in her home in Princeton became overloaded with books, she selected both scientific and other books to send to "the Library in Jerusalem." [63]

However, regardless of the various reasons cited for the distribution of books and other publications, it is clear that they were being constantly received in the Einstein home and were also parted with for working and emotional reasons. In any case a large portion of the books and journals were destined for The Hebrew University in Jerusalem.

In the 1980s, before [64] and after [65] sending Einstein's personal library to Jerusalem Ehud Benamy of the Friends sent to the Jewish National and University Library "books and publications dealing with Einstein." Benamy associated his receipt of such materials with the Friends' permission to reprint Einstein materials. [66] When Benamy granted such permission, he usually requested two copies of the resulting book. It was clear from a letter from Benamy that one of the copies would be deposited in the Archive in Jerusalem. [67]

Parallelly to Benamy's activity, at the beginning of the 1990s staff members of the Archive made a search among Einstein's friends and family for books that had belonged to the scientist. Supplementing information about Einstein's library, in the process they ascertained whether books that had belonged to Einstein contained any notes in Einstein's own hand or any authorial dedications to him. For example, in response to a query by Ze'ev Rosenkranz [68] about books that were given to him by Helen Dukas, Nathan Rosen provided information about the authors and titles of these books, and also about Einstein's notes in them. Rosen wrote: 
"There are no dedications and marginal notations in the books..." [59]

In 1986 Elizabeth Roboz Einstein, the second wife of Einstein's elder son Hans, sent via the Friends, two books: "1. A. Einstein: Ueber die spezielle und die allgemeine Relativitaetstheorie, Sammlung Vieweg, Heft 38, zehnte erweiterte Auflage, Braunschweig 1920; [and] 2. G. Mahler. Physikalische Aufgabensammlung, Sammlung Goeschen Berlin und Leipzig 1917" [69] to the Jewish National and University Library. Under the pressure of repeated requests from Jerusalem, Elizabeth Einstein planned to have sent, after her death [70] an additional " 57 books by and on Albert Einstein." [71]

Some books in the research collection of the Archives were received as donations. Today this collection contains approximately 1,500 items. Many of these items are publications of Einstein's own works, including translations.

\section{Einstein and "A Land of New Beginnings"}

Einstein took an active part in the founding of The Hebrew University in Jerusalem. He felt keenly for the fate of the Jews, especially those born in Eastern Europe, having himself witnessed antisemitism and injustice directed toward Jews in Germany. [72]

His special sympathy for Jews from Eastern Europe was partly based on the studying he experienced in his youth with Max Talmey. [73]

The role of Talmey was significant in the intellectual and emotional development of the young Einstein. A general view shared by Einstein biographers, including Rudolf Kayser [74] and Banesh Hoffmann [75], his contact with Talmey (a medical student who tutored Albert at home) had a decisive influence on Einstein. [76] The above mentioned biographers noted that Jewish Eastern European student Max Talmey stimulated his tutee's interest in science and philosophy, recommending "the popular books on natural science by Aaron Bernstein" [77], and advising Einstein to read Kant. [78]

Ze'ev Rosenkranz stated that the relationship between the tutor and the tutee was later reflected in Einstein's idea of establishing a university, especially of a medical faculty, as a refuge for scientists from the countries of Eastern Europe: "...Einstein, who had been mentored by an Eastern European student of medicine, could repay the favor by contributing to the establishment of a medical faculty for a planned refuge for Ostjuden - the Hebrew University." [79]

Thus, it is hardly surprising that the focus of Einstein's visit to Palestine, from February 2-14 or 15, was connected with the establishment of The Hebrew University. [80]

In his interview on 26 August 1921 [81], Einstein highlighted two main goals for the creation of such a university. The first was the creation of a scientific center that was essential for the healthy functioning of a nation; the second was to provide representatives of Jewish youth, especially from Eastern Europe, with the opportunity to study and gain access to the most up to date scientific achievement, which they were not able to do in Europe. [82]

A primary prerequisite for the creation of such a scientific center was the establishment of a library. [83] Einstein proposed the possibility of using "his name to collect funds for a national library, first for the establishment of a natural science division. He appealed for contribution of books and journals for the library." [84]

In 1924 Einstein corresponded personally with the "Soviet authorities to release the collection" of Baron David Guenzburg, "which contained more that two thousand rare manuscripts." [85] This collection was purchased by Russian Zionists in 1917 for the library in Jerusalem, although its transport was delayed because of war and revolution in Russia. [85]

During his visit to Palestine, the "land of new beginnings" [86] Einstein visited the future national library.

The local newspaper Ha'aretz reported on this visit as follows: "On Monday [February 5] at 5 p.m. Prof. Einstein visited Bet ha-Sefarim ha-Leumi <..> [located in Bayit Ne'eman]. [87] He first visited the reading room, where the readers honored him by rising. From the balcony, he saw a beautiful view of the city and Mr. Peres [the head of personnel at the library] provided him with the necessary explanations. After this Einstein looked at the catalogues and expressed interest in how they were organized. The administration of the library had prepared for their respected guest a selection of Hebrew books on mathematics from the beginning of printing in Hebrew. The guest was amazed by the beauty of the printing. Einstein requested that information be collection about the library and promised to use his influence to encourage people to contribute the funds that were needed for transporting to Palestine the many books that had been collected abroad for the library. The visit lasted an hour and a half." [88]

Zoya Kopel'man summarized another of Einstein's contribution to science at the University as follows: "Einstein viewed The Hebrew University in Jerusalem first of all as a scientific center and [thus,] it is hardly surprising that he became the editor of its first scientific collection [i.e., anthology] ..." [89]

Half a year after Einstein's visit the newspaper Palestine Weekly drew attention to an upcoming event in the scientific life of Palestine -- the issuing of the first scientific collection [of articles] of the future university. It was planned that each issue of the scientific series Scripta would contain four volumes, [on each] in the following scientific fields: “... one on Exact Sciences (mathematics, physics, and technology), which Prof. Albert Einstein is editing; one on Biology and Chemistry, which Prof. A. von Wasserman, of Berlin, is editing; "Litterae Humaniores," of which Prof. E. Cassirer, of Hamburg is editor; and one on the Orient and Judaism, which is being edited by Dr. V. Aptovitzer, of Vienna; Prof. A. Buchler, of London, and Oberrabbiner, Dr. I. Low, of Szeged, 
Hungary." [90] Writing about the soon to appear first volume of the first and fourth groups, the same source noted that "the book will be printed in the original language of the contributor, and in the Hebrew translation." [91]

However, only two volumes of the series in fact appeared. The one on mathematics and physics contained the article by Einstein and Jakob Grommer 'Beweis der Nichtexistenz eines überall regulären zentrisch symmetrischen Feldes nach der Feld-Theorie von Th. Kaluza' (VII, 5 pages) Rec. [received?] 10.I.22.

\section{Conclusions}

Einstein's home library arrived from Princeton to Jerusalem in 1987. The American Friends of The Hebrew University in New York was responsible for packaging and shipping the home collection. With the financial support of the Japan Broadcasting Corporation (NHK), the cataloging of the Einstein's collection was completed by November 1990. The National Library of Israel (formerly the Jewish National and University Library, JNUL) provided a place for Einstein's material, and human resources for the cataloging. Prof. Einstein himself often donated books and journals to the Jewish National and University Library before his library arrived in Israel. In 1948, Einstein also handed over an impressive collection of reprints (of scientific articles by various authors) to The Weizmann Institute.

A significant part of Einstein's home collection was presented to him by writers, scientists, public figures, friends, and relatives. Many of the presents contain dedications to Albert Einstein. The items of the collection are related mostly to literature, philosophy, politics, religions and music.

In 2007 The National Library was split off from The Hebrew University and received independent status according to the National Library Law. [92] A result of this change was that The Einstein Archives (which had been bequeathed to The Hebrew University of Jerusalem) were transferred to new premises at the University. Today the Archives are located on the University's Givat Ram campus, in the Levy building.

\section{Acknowledgements}

I wish to express my deep gratitude to the Archivist Chaya Becker. Her encouragement, provision of indispensable material, and generous sharing of time were invaluable. I also owe a great deal to Barbara Wolff, the Information Officer, who provided me with useful information and advices. Her real love for Einstein's heritage inspired me in the research that led to this paper. My colleagues at The National Library Rini Goldsmith, Hahum Zitter, and Asher Kupchik aided me greatly in my search for the materials I needed. Chaya Meier-Herr and Daniel Lipson provided me with valuable information and Dr. Stefan Litt informed me about the archive of Rudolf Kayser. I owe particular thanks to Dr. Roni Grosz, Curator of The Albert Einstein Archives, for making accessible to me materials that I required and for a willingness to answer my many questions. Olga Stein and Marina Sandler allowed me access to the Einstein reprint collect at The Weizmann Institute of Science. I am grateful to Dr. Yisrael Elliot Cohen, a professional translator, for rendering this article into English. I also wish to acknowledge to aid of all other who answered questions I had or encouraged me in other ways. Finally, I must express my gratitude to my friend Manuel Zkorenblut, who translated sources and quotations from German, and provided me with advice on many occasions.

\section{References}

[1] Albert Einstein Archives, Old Working Files (hereafter AEA OWF) 676, Holton, Gerald. Letter to Ze'ev Rosenkranz, 7 February, 1991. All quotations from AEA sources are with the kind permission of The Albert Einstein Archives at The Hebrew University of Jerusalem.

[2] AEA OWF JNUL 579 1986-87, Beit-Arie, Malachi. Letter to Milton Handler, 2 December, 1986.

[3] AEA OWF 189, NHK - 1989-90.

[4] "I am pleased to inform [you] that I have sent the data on the musical scores and the Hebrew and Yiddish books to you by Express mail Service. <...> Thus, we have completed the cataloguing of Einstein's library...”, ibid., Rosenkranz, Ze'ev. Letter to Haruki Kito, 8 November, 1990.

[5] AEA OWF 189, NHK - 1989-90, Rosenkranz, Ze'ev. Letter to [Milton] Handler via [Amnon] Pazy, 25 June, 1990. A CDROM format of this Japanese television series can be found at The Einstein Archives.

[6] AEA OWF 189, NHK - 1989-90, 'Regarding International Academic Publication of the Catalogue of the Einstein Library'.

[7] AEA, Archival Call Number (hereafter Archival Call Number): 75-412, pp. 2-6, citation p. 3 .

[8] AEA OWF 189, NHK - 1989-90, 'Protocol, Subject: Catalogue of the Einstein Library' (Hebrew).

[9] Archival Call Number: 75-412, p. 3.

[10] Calaprice, Alice, Daniel Kennefick, and Robert Schulmann, An Einstein Encyclopedia (Princeton: Princeton University Press, 2015), p. 10.

[11] AEA OWF 676, Rosenkranz, Ze'ev. Letter to Gerald Holton, 16 January, 1990, pp. [1-3], citation p. [2].

[12] AEA OWF 189, NHK - 1989-90, Rosenkranz, Ze'ev. Letter to Haruki Kito, 25 July, 1990.

[13] AEA OWF JNUL 581, 1988-90, Rosenkranz, Ze'ev. Letter to Ehud Benamy, 18 December, 1989.

[14] AEA OWF JNUL 581, 1988-90, Rosenkranz, Ze'ev. Letter to Ehud Benamy, 24 January, 1990.

[15] AEA OWF JNUL 581, 1988-90, Benamy, Ehud. Letter to Ze'ev Rosenkranz, 8 February, 1990.

[16] AEA OWF JNUL 581, 1988-90, Benamy, Ehud. Letter to Ze'ev Rosenkranz, 11 January, 1990. 
[17] AEA OWF 676, Holton, Gerald. Letter to Ze'ev Rosenkranz, 14 January, 1991.

[18] AEA OWF 676, Rosenkranz, Ze'ev. Letter to Gerald Holton, 4 March, 1990.

[19] AEA OWF 676, Rosenkranz, Ze'ev. Letter to Gerald Holton, 16 January, 1990, p. [2]. 'List of publications on relativity' see Archival Call Number: 43-396 (Rosenkranz gives the number of the item in the Archives in his letter).

[20] AEA OWF 676, Rosenkranz, Ze'ev. Letter to Gerald Holton, 16 January, 1990, p. [3]. In his list of relevance sources of information "regarding the history of the library" Rosenkranz refers to this letter of Einstein, citing it, and giving its Archival Call Number, 73-052. Rosenkranz also cites here the "letter from Prof. Otto Fanta to Einstein (Prague, 4.1.1939)" (German) on the same subject, citing Archival Call Number: 53-040.

[21] See also Calaprice, Alice (2015), p. 106.

[22] The Kayser Archive and his personal library were donated to the JNUL. $<$ http://web.nli.org.il/sites/NLI/English/collections/persona 1sites/archive_treasures/Pages/kayser.aspx $>$ [accessed 25 November 2017]. The Kayser Archive includes biographical material, correspondence, teaching materials, works, etc. Among Kayser's personal effects in the archive is a bronze mask of his first wife Ilse Einstein made after she died by her sister, the sculptor Margot Einstein (Bronzebüste Ilse Kayser. Archival Call Number in JNUL: ARC 4* 1820130 ).

[23] Calaprice, Alice (2015), p. 10.

[24] Bucky, Peter A., in Zusammenarbeit mit Allen G. Weakland. Der private Albert Einstein: Gespräche über Gott, die Menschen und die Bombe. Aus dem Amerikanischen von Kurt Simon (Düsseldorf: ECON Verlag, 1991), p. 87.

[25] Archival Call Number: 32-583, Dukas, Helen. Letter to Otto Nathan, 28 March, 1958 (German), cited in AEA OWF 676, Rosenkranz, Ze'ev. Letter to Gerald Holton, 16 January, 1990.

[26] Pais, A., Nauchnaya deyatel'nost' i zhizn' Al'berta Einshteina (The Scientific Activity and Life of Albert Einstein). Translation from English by V. I. and O. I. Matsarskii, edited by A. A. Logunov (Moscow: Nauka, 1989), p. 305. Originally: Abraham Pais, Subtle Is the Lord...: The Science and the Life of Albert Einstein (Oxford: Oxford University Press, 1982), p. 317.

[27] Archival Call Number: 29-175, Einstein, Albert. 'Last Will and Testament', pp. 1-10.

[28] Archival Call Number: 29-175, Einstein, Albert. 'Last Will and Testament', p. 2.

[29] Archival Call Number: 29-175, Einstein, Albert. 'Last Will and Testament', p. 8.

[30] Archival Call Number: 29-175, Einstein, Albert. 'Last Will and Testament', p. 6.

[31] Calaprice, Alice (2015), p. 11.

[32] On this see also in Calaprice, Alice (2015), p. 12.

[33] AEA OWF 579 1986-87, Cohn, Margot. Letter to Ehud Behamy, 26 January, 1987.
[34] AEA OWF 579 1986-87, Benamy, Ehud. Letter to Margot Cohn, 15 January, 1987.

[35] AEA OWF 579 1986-87, Benamy, Ehud. Letter to Margot Cohn, 25 August, 1987.

[36] Kirjath Sepher, 22: 1945-46, p. 179.

[37] Kirjath Sepher, 24: 1947-1948, p. 287.

[38] "During its first years (1924-1927) it [Kiryat Sefer=Kirjath Sepher] was edited by Gershom Scholem and later by Issachar Joel (1928-1968) ...", cited from Baras, Zvi, A Century of Books: The Jewish National \& University Library, 1892-1992 (Jerusalem: Berman Hall/The Jewish National and University Library, 1992), p. 65.

[39] Kirjath Sepher, 8: 3 (1932), 284, in the section "Yediyot Beit ha-Sefarim" ("News from the library") (Hebrew). This special section existed until 1950 (see note 38).

[40] "Prof. Albert Einstein (of Princeton, New Jersey) has sent several books that were published in recent years." Cited from Kirjath Sepher, 17: 1 (1940), 4 (Hebrew).

[41] Baras, Zvi, A Century of Books: The Jewish National \& University Library, 1892-1992 (Jerusalem: Berman Hall/The Jewish National and University Library, 1992), p. $p=110$ (Hebrew).

[42] "In America Einstein had often been regarded officially as a leader of the Jewish people", cited from Frank, Philipp, Einstein: His Life and Times. Translated from a German manuscript by G. Rosen; edited and revised by S. Kusaka (New York: Knopf, 1953); reprint (New York: Da Capo Press, 1989), p. 280.

[43] AEA 67-706, Wormann, Curt. Letter to Albert Einstein, 5 February, 1953.

[44] Cited in Hoffmann, Banesh, Albert Einstein: Creator and Rebel (New York: The Viking Press, 1972), p. [151].

[45] Kuf-Lamed [K. L.] (author's initials), 'Harza'at ha-profesor Einstein al Har ha-Tsofim' ('Prof. Einstein's Lecture on Mount Scopus'), Ha'aretz, vol. 4, no. 1060 (Feb. 11, 1923), p. 3 (Hebrew).

[46] 'Delayed tribute for a revolutionary idea', The Jerusalem Post (January 18, 1980), p. 9.

[47] On such contacts see, for example, Levenson, Thomas, Einstein in Berlin (New York: Bantam Books, 2003), pp. 2324.

[48] It should be noted that the National Library also reported the receipt of a collection of reprints from Einstein: "A gift from Prof. Einstein, [from] Princeton, a collection of reprints of various scientific articles." Cited from Kirjath Sepher, 23: 1 (1946-47), 255 (Hebrew).

[49] The Einstein reprint collection (in fifty-nine volumes) at The Weizmann Institute of Science, vol. 34.

[50] The Einstein reprint collection (in fifty-nine volumes) at The Weizmann Institute of Science, vol. 54.

[51] The Einstein reprint collection (in fifty-nine volumes) at The Weizmann Institute of Science, vol. 13.

[52] The Einstein reprint collection (in fifty-nine volumes) at The Weizmann Institute of Science, vol. 17. 
[53] A copy of the French-language original of the biography of Marie Curie, Madame Curie (Paris: Gallimard, 1938), written by her daughter Eve Curie, is located at The Einstein Archives, along with the German translation Madame Curie: Leben und Wirken (Wien: Bermann-Fischer Verlag, 1937). The French version contains the author's handwritten dedication to Albert Einstein: “ă Albert Einstein Hommage de fervente admiration et de sympathie [from] EveCurie" ("To Albert Einstein, A tribute of fervent admiration and sympathy"). I would like to thank Paloma Tulman for deciphering this handwritten French dedication, as well as other handwritten dedications in French.

[54] The Einstein reprint collection (in fifty-nine volumes) at The Weizmann Institute of Science, vol. 11.

[55] AEA OWF 676, Holton, Gerald. Letter to Ze'ev Rosenkranz, 16 March, 1990.

[56] Calaprice, Alice (2015), p. 137.

[57] Stachel, John, 'The Formative Years', in Howard, Don [and] John Stachel, eds. Einstein: the Formative Years, 1879-1909. Einstein studies 8 (Boston: Birkhäuser, 2000), pp. [1]-22, citation p. 16 , note 22 .

[58] "Naturally I am well acquainted with your principal works, of which I especially admire the one on mechanics." - from Einstein's letter to Ernst Mach, [9 August 1909], in The Collected Papers of Albert Einstein. English translation. Vol. 5, The Swiss Years: Correspondence, 1902-1914. Martin J. Klein et al., eds. Anna Beck, translator (Princeton: Princeton University Press, 1995), Doc. 174, p. 130; cited in Stachel, John. 'Introduction to Einstein: The Formative Years', in Stachel, John, ed. Einstein from ' $B$ ' to ' $Z$ '. Einstein studies 9 (Boston: Birkhäuser, 2002), pp. 121-139, citation p. 125; Einstein referred to this book in 'Autobiographical Notes', in Albert Einstein: PhilosopherScientist, Vol. 1, Schilpp, Paul Arthur, ed. (New York: Harper Torchbooks/Science Library, 1959), pp. 1-95, see p. 21.

[59] AEA OWF 676, Rosen, Nathan. Letter to Ze'ev Rosenkranz, 19 July, 1990 (Hebrew).

[60] AEA OWF 676, Jost, Res. Letter to Ze'ev Rosenkranz, 14 August, 1990.

[61] AEA OWF 676, Holton, Gerald. Letter to Haruki Kito, 29 May, 1990.

[62] 'Albert Einstein Archives: The History of the Archives'. In Albert Einstein: the Persistent Illusion of Transcience, the Albert Einstein Archives, ed., Z. Rosenkranz, B. Wolff, Engl. ed., revised and substantially enlarged (Jerusalem: Magnes Press, 2007), p. 258. About Gerald Holton's help to Helen Dukas see also in Calaprice, Alice (2015), p. 31.

[63] AEA OWF Misc. Corr. Estate T-Z, Dukas, Helen. Letter to Rabbi J. J. Weinstein, after 4 May 1971.

[64] See, for example JNUL 578 1985-86, Benamy, Ehud. Letter to Margot Cohn, 25 September, 1986; Cohn, Margot. Letter to Ehud Benamy, 29 July, 1986; Benamy, Ehud. Letter to Mordecai Nadav [was the head of the Department of Manuscripts \& Archives], 13 February, 1986; Nadav, Mordecai. Letter to Ehud Benamy, 30 January, 1986; Benamy, Ehud. Letter to Mordecai Nadav, 24 December, 1985; Nadav, Mordecai. Letter to Ehud Benamy, 13 December, 1985.

[65] See, for example JNUL 579 1986-87, Cohn, Margot. Letters to Ehud Benamy, 4 October, 1987, and 7 December, 1987.

[66] AEA OWF 580 1987-89, Benamy, Ehud. Letter to Margot
Cohn, 2 November, 1989.

[67] AEA OWF 579 1986-87, Benamy, Ehud. Letter to Margot Cohn, 10 February, 1987.

[68] AEA OWF 676, Rosenkranz, Ze'ev. Letter to Nathan Rosen, 15 July, 1990 (Hebrew).

[69] See the letter of thanks for her AEA OWF JNUL 578 1985-86, Cohn, Margot. Letter to Elizabeth R. Einstein, 29 July, 1986.

[70] AEA OWF JNUL 578 1985-86, Einstein, Elizabeth R. Letter to Roy Calder, 23 October, 1985.

[71] AEA OWF JNUL 578 1985-86, Nadav, Mordecai. Letter to Ehud Benamy, 9 September, 1985.

[72] 'How I became a Zionist' in The Collected Papers of Albert Einstein. English translation. V. 7, The Berlin Years: Writings, 1918-1921. Michel Janssen et al., eds. Translated by Alfred Engel (Princeton: Princeton University Press, 2002), pp. [234]-237, citation pp. 235-236; also in Kopel'man, Zoya, comp. and ed., translation: Yu. Miller, Al'bert Einshtein: obresti dostoinstvo $i$ svobodu (Jerusalem; Moscow: Gesharim/Mosty Kul'tury, 2006), pp. 37-42, citation p. 40.

[73] Rosenkranz, Ze'ev, Einstein before Israel: Zionist Icon or Iconoclast? (Princeton: Princeton University Press, 2011), pp. 21-22.

[74] Reiser, Anton, Albert Einstein: A Biographical Portrait (New York: Albert and Charles Boni, 1930), pp. 36-37.

[75] Hoffman, Banesh, with the collaboration of Helen Dukas, Albert Einstein: Creator and Rebel (New York: The Viking Press, 1972), p. 24.

[76] The Einstein library contains two books written by Max Talmey (Talmud). The Relativity Theory Simplified: and the Formative Period of Its Inventor, with an introduction by George B. Pegram, (New York: Falcon Press, 1932) \& Psyche: A Concise and Easily Comprehensible Treatise on the Elements of Psychiatry and Psychology: for Students of Medicine and Law (New York: Medico-Legal Pub. Co., 1910); the second book contains a handwritten dedication to Einstein by the author: "A loken of longstanding friendship to Professor Albert Einstein Max Talmey, October 17, 1937'. The Weizmann Institute's the Einstein reprint collection contains a typewritten copy of the text of the lecture by Max Talmey 'Origin and Essence of the Nordic-Aryan Fabrication' (New York City, February 1936), V. 56 Miscellaneous S-Z, pp. [1] -10.

[77] Reiser, Anton (1930), p. 36. Bernstein's Naturwissenschaftliche Volksbücher [Popular Books on Natural Sciences] are mentioned along with the books Kraft und Stoff [Force and Matter] by Büchner, and Kosmos by Humboldt, which were recommended for reading "among others" by Talmey, in Winteler-Einstein, Maja, 'Albert Einstein-a Biographical Sketch' (Excerpt). In The Collected Papers of Albert Einstein. English translation. Vol. 1, The Early Years, 1879-1902. John Stachel et al., eds. Anna Beck, translator (Princeton: Princeton University Press, 1987), pp. xvxxii, citation $\mathrm{p}$. xxi.

[78] Hoffmann, Banesh (1972), p. 24.

[79] Rosenkranz, Ze'ev (2011), p. 138.

[80] For detailed list of places visited by Einstein in Palestine and information about speeches he gave there (both mainly based on the local press) see Ze'ev Rosenkranz, 'Secular Pilgrim or Zionist Tourist? Einstein's Tour of Palestine in 1923' (pp. 139180), in Einstein before Israel. 
[81] Einstein, Albert, 'On the Founding of the Hebrew University in Jerusalem'. Published 26 August 1921. In: Jüdische Pressezentrale Zürich, 26 August 1921, p. [1]. (An interview by the "Jüdische Pressezentrale Zürich" with Professor Einstein, August 26, 1921), in The Collected Papers of Albert Einstein. English translation. V. 7, pp. [248]-249; also in Russian translation under the title ' $O$ sozdanii Evreiskogo universiteta v Ierusalime', in Kopel'man, Zoya (2006), pp. 5051.

[82] Einstein, Albert, 'On the Founding of the Hebrew University in Jerusalem', in The Collected Papers of Albert Einstein. English translation. V. 7, pp. [248]-249.

[83] The plan for the establishment of a national library, that was always linked to the establishment of a university, influenced the construction of Beit ha-Sefarim ha-Leumi vehaUniversitai as a national and university library. See Katz, Shaul [and] Heyd, Michael, eds., The History of the Hebrew University of Jerusalem: Origins and Beginnings (Jerusalem: The Magnes Press, 1997), p. 151 (Hebrew).

[84] Kopel'man, Zoya (2006), p. 57.

[85] Baras, Zvi (1992), p. 42.

[86] “...Einstein perceived Palestine as "a land of new beginnings."' Cited from Rosenkranz, Ze'ev (2011), p. 178.

[87] "Bayit Ne'eman" was built as a first "permanent home for" the Jewish National Library. In A Century of Books (1992), p. 28. This building in Jerusalem at Bnei Brit Street No. 18 does not have a balcony, as stated in the newspaper Ha'aretz [in its report of Einstein's visit] (see note 88). However, on the lot next to it there is another two-storey building (Bnei Brit St. No. 16) whose upper storey does have a balcony. The history of the National Library began in 1892 with the establishment of "Midrash Abrabanel Library". "The name "Midrash Abrabanel", which hinted at a 'house of study' (Beit Midrash), was chosen to allay the suspicion of the Ottoman authorities who would oppose the establishment of any new institution that seemed to have a nationalist character." In A Century of Books (1992), p. 20.

[88] 'Ha-profesor Einstein be-Veit ha-Sefarim ha-Leumi' ('Prof. Einstein at the Beit ha-Sefarim ha-Leumi'), Ha'aretz, vol. 4, no. 1058,8 February, 1923, p. 3 (Hebrew).

[89] Kopel'man, Zoya (2006), p. 55.

[90] 'Jerusalem University Publication', The Palestine Weekly, vol. 5, no. 34, 31 August, 1923, pp. 163-164, citation p. 163.

[91] 'Jerusalem University Publication', The Palestine Weekly, vol. 5, no. 34, 31 August, 1923, p. 164.

[92] The National Library Law, 5768-2007, complete and updated version

$<$ http://web.nli.org.il/sites/NLI/English/library/aboutus/past/D ocuments/The\%20National\%20Library\%20Law\%2057682007.pdf $>$ [accessed 25 November 2017].

\section{Biography}

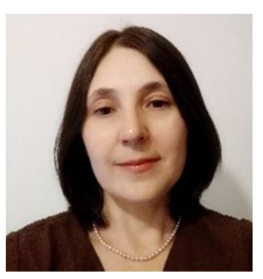

Marianna Gelfand is a Senior Librarian, who works at the Library Authority Department of The Hebrew University and The Albert Einstein Archives. She has a master's degree in Library Sciences and a doctorate in Russian Literature, both from The Hebrew University. Marianna Gelfand was born in 1969, in the former Soviet Union, and arrived in Israel in 1991. She is a member of the Cataloging Committee of The Hebrew University, a representative of the Hebrew University Catalog to the National Cataloging Committee, and a member of the Israel Association of Librarians and Information Professionals. 